\title{
A new drug combination significantly reduces kidney tumor progression in kidney mouse model
}

\author{
Sitai Liang ${ }^{1}$, Tiffanie Cuellar ${ }^{1}$, Maciej Nowacki ${ }^{1}$, Bijaya K. Nayak ${ }^{1}$, Lily Dong ${ }^{1}$, Boajie \\ $\mathbf{L i}^{3}$, Kumar Sharma ${ }^{2}$ and Samy L. Habib ${ }^{1,4}$ \\ ${ }^{1}$ Department of Cell Systems \& Anatomy, University of Texas Health Science Center at San Antonio, Bio-X Institutes, San \\ Antonio, TX, USA \\ ${ }^{2}$ Department of Medicine, University of Texas Health Science Center at San Antonio, Bio-X Institutes, San Antonio, TX, USA \\ ${ }^{3}$ Shanghai Jiao Tong University, Shanghai, China \\ ${ }^{4}$ South Texas Veterans Health Care System, San Antonio, TX, USA \\ Correspondence to: Samy L. Habib, email: habib@uthscsa.edu
}

Keywords: kidney tumor; rapamycin; AICAR; HIF2a; TSC2

Received: March 24, $2018 \quad$ Accepted: July 27, 2018

Published: August 31, 2018

Copyright: Liang et al. This is an open-access article distributed under the terms of the Creative Commons Attribution License 3.0 (CC BY 3.0), which permits unrestricted use, distribution, and reproduction in any medium, provided the original author and source are credited.

\section{ABSTRACT}

Tuberous sclerosis complex (TSC) disease is associated with tumors in many organs, particularly angiomyolipoma (AML) in the kidneys. Loss or inactivation of TSC1/2 results in high levels of HIF-a activity and VEGF expression. mTOR inhibitor (rapamycin) and the AMPK activator 5-aminoimidazole-4-carboxamide (AICA)-riboside (AICAR) are currently used separately to treat cancer patients. Here, we investigated the effect of a novel combination of rapamycin and AICAR on tumor progression. Our data show that treatment of AML human cells with drug combinations resulted in 5-7-fold increase in cell apoptosis compared to each drug alone. In addition, drug combinations resulted in 4-5-fold decrease in cell proliferation compared to each drug alone. We found that drug combinations abolished Akt and HIF activity in AML cells. The drug combinations resulted in decrease in cell invasion and cell immigration by $70 \%$ and $84 \%$, respectively in AML cells. The combined drugs also significantly decreased the VEGF expression compare to each drug alone in AML cells. Drug combinations effectively abolished binding of HIF-2a to the putative Akt site in the nuclear extracts isolated from AML cells. Treatment TSC mice with drug combinations resulted in $\mathbf{7 5 \%}$ decrease in tumor number and $\mathbf{8 8} \%$ decrease in tumor volume compared to control TSC mice. This is first evidence that drug combinations are effective in reducing size and number of kidney tumors without any toxic effect on kidney. These data will provide evidence for initiating a new clinical trial for treatment of TSC patients.

\section{INTRODUCTION}

Tuberous Sclerosis Complex (TSC) affects around 25,000 to 50,000 individuals in the United States and about 1 to 2 million individuals worldwide, with an estimated prevalence of one in 6,000 newborns. TSC is characterized by the development of benign and/or malignant tumors in several organs including renal angiomyolipomas, facial angiofibroma, lymphangiomyomatosis, cardiac rhabdomyomas, retinal astrocytic, renal cell carcinoma, and brain subependymal giant cell astrocytomas [1-
4]. Multicentric angiomyolipomas (AMLs) are much more common in patients with tuberous sclerosis than renal cell carcinoma, but may nonetheless have similar underlying genetic basis at early steps in their genesis and/or progression, specifically in the setting of tuberin deficiency $[2,3]$. Renal AMLs are associated with TSC tend to be larger, bilateral, multifocal and present at a younger age compared with sporadic forms. The metastatic spread of AML cells from kidney to the lung manifests tumor growth causing a cystic destruction of the lung and lung collapse [5-7]. 
Loss or inactivation of TSC1/2 genes in TSC patients results in persistent activation of Akt and mTOR (major protein kinases involved in several types of tumors), and hyperactivation of the transcription factors Hypoxia-Inducible Factors (HIF- $1 \alpha$ and $-2 \alpha$ ) $[8,9]$. Hyperactivation of HIF- $1 / 2 \alpha$ in turn is positively associated with the upregulation of Vascular Endothelial Growth Factor (VEGF), a key factor in tumorigenesis and metastasis $[10,11]$. Increased expression of VEGF is also associated with malignant progression and a poor treatment outcome [12]. These findings suggest that suppressing the HIF-mediated, hypoxia-induced VEGF gene pathway may be an important therapeutic strategy for the treatment of tumorigenesis in TSC. The relative contribution of HIF- $1 \alpha$ to VEGF regulation in TSC has not yet been fully explored. The mTOR inhibitor rapamycin is also being studied as a cancer drug, both pre-clinically and clinically, but its efficacy is reported to vary with different cancer types [13-15]. On the other hand, AMP Kinase is the primary energy sensor in cells and activates tumor suppressor genes TSC to block HIF activity. The pharmacological activator of AMPK, 5-aminoimidazole4-carboxamide (AICA)-riboside, or AICAR, inhibits the growth and survival of glioblastoma cells and is currently being tested as a cancer treatment [16]. Recent published data from our laboratory show that significant inhibition of mTOR by rapamycin and activation of AMPK by AICAR in several kidney tumor cells isolated from $\mathrm{TSC2}^{+/}$mouse model [17]. We propose novel drug combinations to target the HIF/VEGF pathways to reduce tumor progression and metastasis in patients with TSC.

There are no current clinical studies using rapamycin+AICAR combination for the treatment of patients with TSC. Since rapamycin and AICAR have already been approved, and each is used separately in clinical studies (see ClinicalTrial.gov in Reference section), we propose a novel combination of rapamycin+AICAR for treatment TSC patients. Our data showed that no synergistic toxic effect of drug combinations in normal renal cells while drug combinations has stronger effect than each drug alone on inhibiting the proliferation and increased apoptosis in AML cells isolated from TSC patients and in $\mathrm{TSC}_{2}{ }^{+/}$and $\mathrm{TSC}^{-/}$cells isolated from kidney of $\mathrm{TSC}^{+/}$mice. Data from our study will provide important base-line data for clinical trials in TSC patients with kidney tumor.

\section{RESULTS}

\section{Drug combinations has strong effect to induce cell apoptosis in AML cells}

To test the effective dose of each drug or the synergistic effect of drug combinations on cell apoptosis, cells treated with serial concentrations of AICAR (0$10 \mathrm{mM})$ or rapamycin $(0-100 \mathrm{nM})$ or combination of both drugs $(2 / 20,4 / 40,10 / 100, \mathrm{mM} / \mathrm{nM})$ for $72 \mathrm{hrs}$. AML cells treated with rapamycin or AICAR show increase in number of apoptotic cells, which is dose dependent with maximum of 3 -fold with AICAR $(10 \mathrm{mM})$ and 2 fold with rapamycin $(20 \mathrm{nM})$ compared to non-treated cells measured by annexin $\mathrm{V}$ assay (Figure 1A \& 1B). On the other hand, the most effective low dose of combined drugs $(2 / 20, \mathrm{mM} / \mathrm{nM})$ showed 10 -fold increase in number of apoptotic cells compared to non-treated cells (Figure 1C). In addition, cells were treated with drug combinations ( $2 \mathrm{mM} / 20 \mathrm{nM}$, AICAR/Rapa) for different time points (24, 48 and $72 \mathrm{hrs)} \mathrm{show} \mathrm{that} \mathrm{increase} \mathrm{in} \mathrm{cell} \mathrm{apoptosis}$ is associated with increase exposure time of the cells to drugs (Figure 1D). Furthermore, we confirmed the increase in apoptosis proteins in cells treated with each drug and drug combinations by measuring cleavage of PARP at $85 \mathrm{kDa}$ and Caspase 3 at 22, 17, $11 \mathrm{kDa}$ products (Figure 1E \& 1F), confirming that the combination of drugs has strongest effect on increasing the apoptosis cascade pathway compared to cells treated with each drug alone.

\section{Drug combinations significantly decreased cell proliferation in AML cells}

Since cell proliferation is necessary for tumor progression, we tested the effect of each drug or drug combinations on cell proliferation. AML cells were treated with serial concentrations of AICAR $(0-10 \mathrm{mM})$ or rapamycin $(0-100 \mathrm{nM})$ or combination of both drugs $(2 / 20$, $4 / 40,10 / 100, \mathrm{mM} / \mathrm{nM}$ ) for $72 \mathrm{hrs}$. The $\left[{ }^{3} \mathrm{H}\right]$-Thymidine incorporation assay performed in all treated cells showed that the decrease in cell proliferation is dose dependent for each drug alone. Cells treated with rapamycin or AICAR show a dose dependent decrease in number of proliferative cells, with maximum of 1-fold decrease at highest dose of each drug compared to non-treated cells (Figure 2A \& 2B). On the other hand, the decrease in the cell proliferation show strong dose dependent effect from 2/20, 4/40 and 10/100 mM/nM AICAR/rapamycin, (8-9 fold decrease), with the most effective lowest dose of combined drugs of $2 \mathrm{mM} / 20 \mathrm{nM}$ compared to non-treated cells (Figure $2 \mathrm{C}$ ). In addition, cells were treated with drug combinations $(2 \mathrm{mM} / 20 \mathrm{nM}$, AICAR/Rapa) for different time points (24, 48 and $72 \mathrm{hrs}$ ) show that decrease in cell proliferation is associated with increase in the exposure time of the cells to drugs (Figure 2D). Furthermore, we confirmed the decrease in cell proliferative proteins in both cells treated with each drug and most effectively in cells treated with drug combinations measured by protein expression of PCNA and cyclin D1 (Figure 2E \& 2F). Significant decrease in both proliferative proteins expression was observed in cells treated with drug combinations compared 
to each drug alone (Figure $2 \mathrm{E} \& 2 \mathrm{~F}$ ). These data suggest that combined drug has strong synergistic effect compared to each drug alone to decrease cell proliferation and slow the tumor progression.

\section{Drug combinations is more effective to block survival kinase (Akt) and to abolish HIF expression in AML cells}

Hyperactivation of $\mathrm{Akt}$ and $\mathrm{mTOR}$, the major protein kinases were detected in several types of tumors. In addition, overexpression of the transcription factors Hypoxia-Inducible Factors HIF- $1 \alpha$ and $-2 \alpha$ was linked to tumor progression of kidney tumorigenesis. Next, we tested the effect of each drug or drug combinations on phosphorylation of Akt, and protein expression of HIF-
$2 \alpha$ in renal AML cells. Cells were treated with rapamycin $(20 \mathrm{nM})$ or AICAR $(2 \mathrm{mM})$ or drug combinations $(20 \mathrm{nM}$ rap/2 mM AICAR) for $72 \mathrm{hrs}$. Cells treated with single drug show significant decrease in $\mathrm{p}$-Akt) compared to control (Figure 3A). On the other hand, combination of drugs nearly abolished phosphorylation of Akt at Ser ${ }^{473}$ (Figure 3A) and abolished HIF-2 $\alpha$ protein expression (Figure $3 \mathrm{~A}$ ) indicating that the combination of the drug has more effect than each drug alone in blocking activation of Akt/HIF-2 $\alpha$ pathway.

\section{Drug combinations is more effective on decreasing Akt promoter activity in AML cells}

Akt promoter reporter plasmid was transfected and Renilla reporter plasmid (pRL-null) as transfection control
A

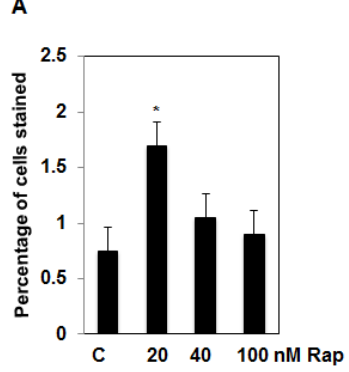

B

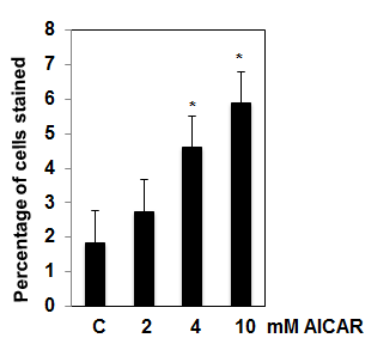

C

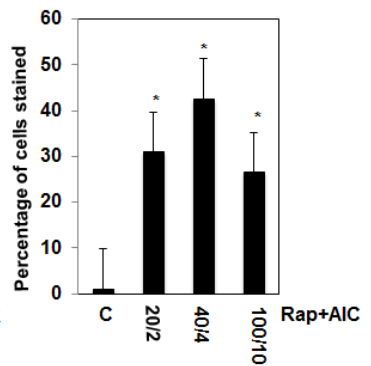

D

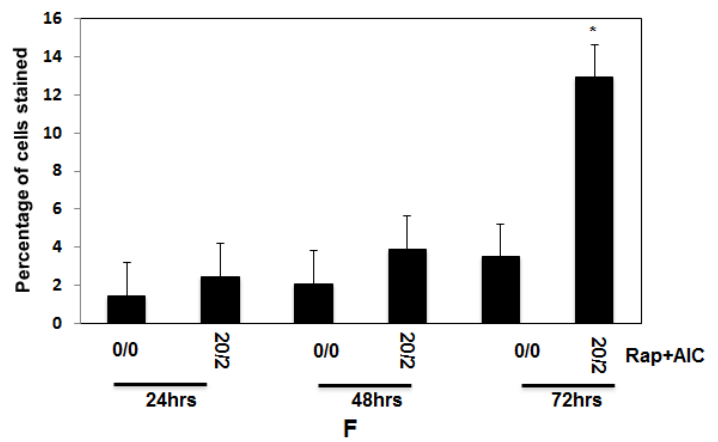

E

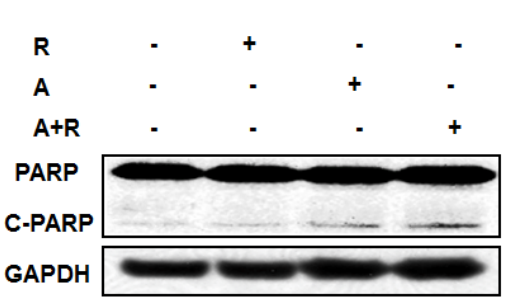

F

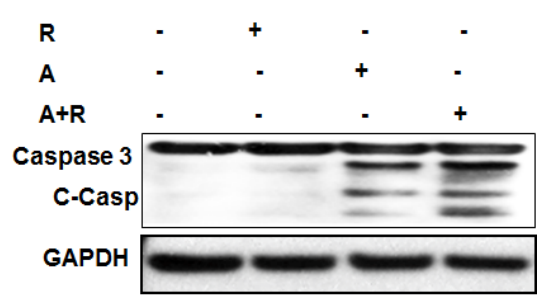

Figure 1: Significant increase in number apoptotic cells is dependent on drug concentration and duration of exposure in AML cells. Serial concentrations of A., rapamycin (0-100nM), B. AICAR (0-10mM) C., drug combinations (0/0-2/20,4/40 and 10/100 $\mathrm{mM} / \mathrm{nM}$ ) in cells treated for $72 \mathrm{hrs}$ show that increase in number of apoptotic cells is dose-dependent using annexin V-FITC conjugated to PI by flow cytometry. In addition, treatment of the cells with drug combinations for 24,48 , and $72 \mathrm{hrs} \mathbf{D}$., show that increase in number of apoptotic cells is time dependent. Apoptotic data was confirmed in cells by measuring apoptotic protein expression. Lysates from cells treated with rapmycin $(20 \mathrm{nM})$, AICAR $(2 \mathrm{mM})$, rapamycin+AICAR $(20 \mathrm{nM} / 2 \mathrm{mM})$ for $72 \mathrm{hrs}$ were subjected to Western blot analysis to measure PARP and caspase 3 cleavages. E. \& F. Significant increase was detected in cleavage of PARP at 85 KDa and caspase 3 at 22,17 and $11 \mathrm{KDa}$ in AML cells treated with drug combinations compared to cells treated with each drug alone for 72hrs. GAPDH was used as a loading control. Data represent means $\pm \mathrm{SE}(n=4)$. Significant difference from control tissues is indicated by $* P<0.01$. 
into AML cells as described in M\&M section. Cells were treated with rapamycin $(20 \mathrm{nM})$ or AICAR $(2 \mathrm{mM})$ or drug combinations (20 nM rap/2 mM AICAR) for $72 \mathrm{hrs}$. Cells were harvested for firefly and Renilla luciferase assay using Dual-Luciferase Reporter assay kit. Data in Figure 3B show that each drug treatment has significant effect on decrease luciferase activity of Akt promoter activity compared to control cells. On the other hand, treatment of the cells with drug combinations showed close to $70 \%$ decrease in the Akt promoter activity compared to control cells suggesting that the synergistic effect of the combined drugs is sufficient to block the promoter activity of the major transcription factor that involve in kidney cancer. These data suggest that drug combinations have a strong
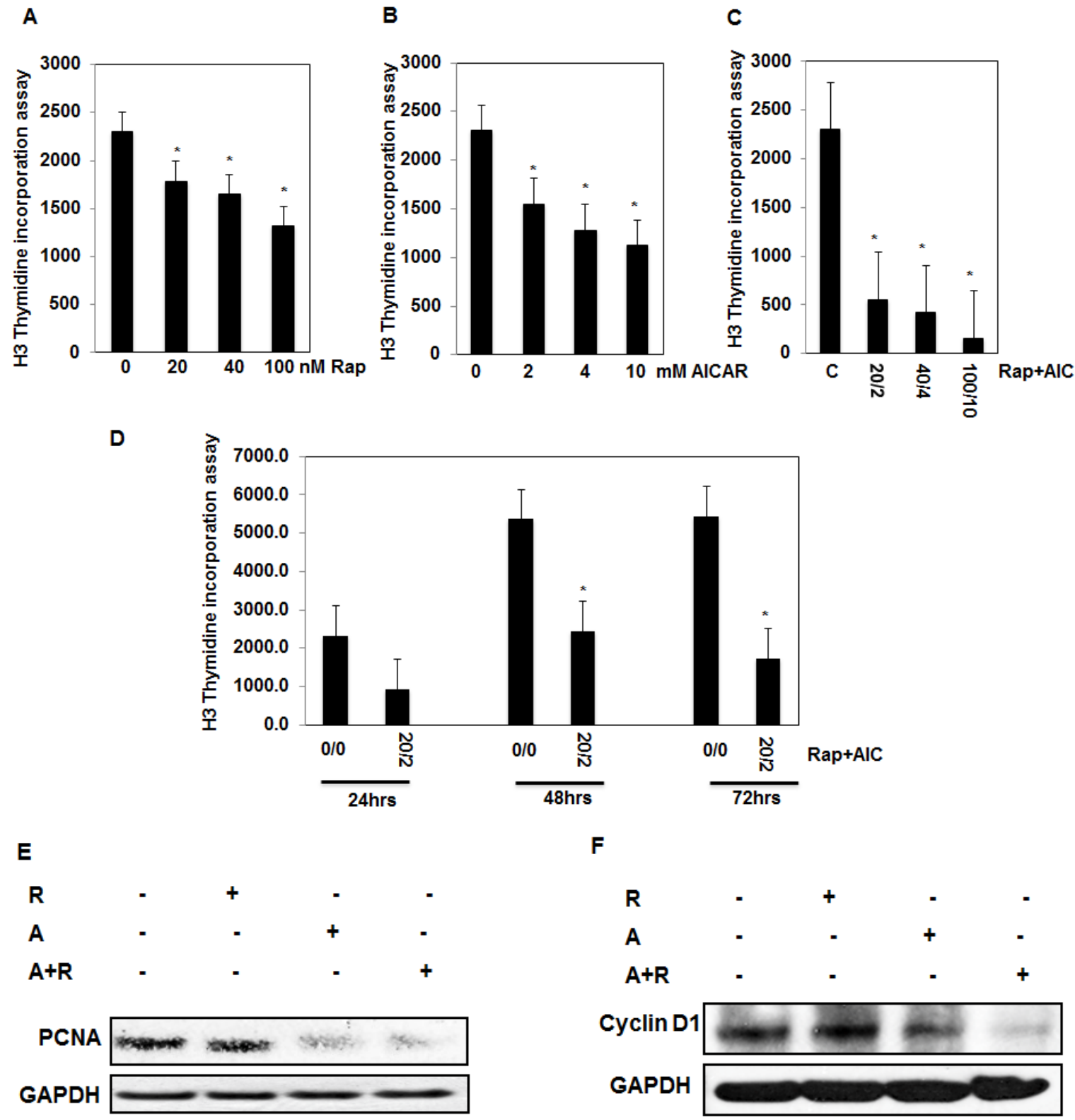

Figure 2: Decrease cell proliferation in response to drug combinations is dependent on the drug concentration and duration of exposure in AML cells. Serial concentrations of A., rapamycin (0-100nM), B., AICAR (0-10mM) C., drug combinations $(0 / 0-2 / 20,4 / 40$ and $10 / 100 \mathrm{mM} / \mathrm{nM})$ in cells treated for $72 \mathrm{hrs}$ showed that decrease in cell proliferation is dose-dependent using ${ }^{3} \mathrm{H}$-thymidine incorporation assay. In addition, treatment of the cells with drug combinations for 24, 48, and $72 \mathrm{hrs}$ D., showed that significant decrease in cell proliferation is time dependent. Cell proliferation data was confirmed by measuring proliferative protein expression. Lysates from cells treated with rapmycin $(20 \mathrm{nM})$, AICAR $(2 \mathrm{mM})$, rapamycin+AICAR $(20 \mathrm{nM} / 2 \mathrm{mM})$ for $72 \mathrm{hrs}$ were subjected to Western blot analysis to measure PCNA and cyclin D1. E. \& F. Significant decrease in expression of PCNA and cyclin D1 was detected in cells treated with single drug while abolishment of expression of both proteins detected in cells treated with drug combinations providing evidence of the synergistic effect of drug combinations on reducing cell proliferation. GAPDH was used as a loading control. Data represent means \pm SE $(n$ $=4)$. Significant difference from control tissues is indicated by $* P 0.01$. 
A

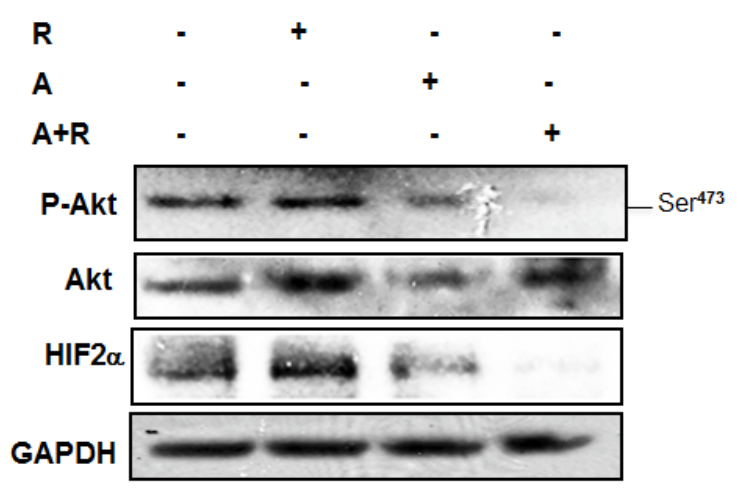

$\mathbf{B}$

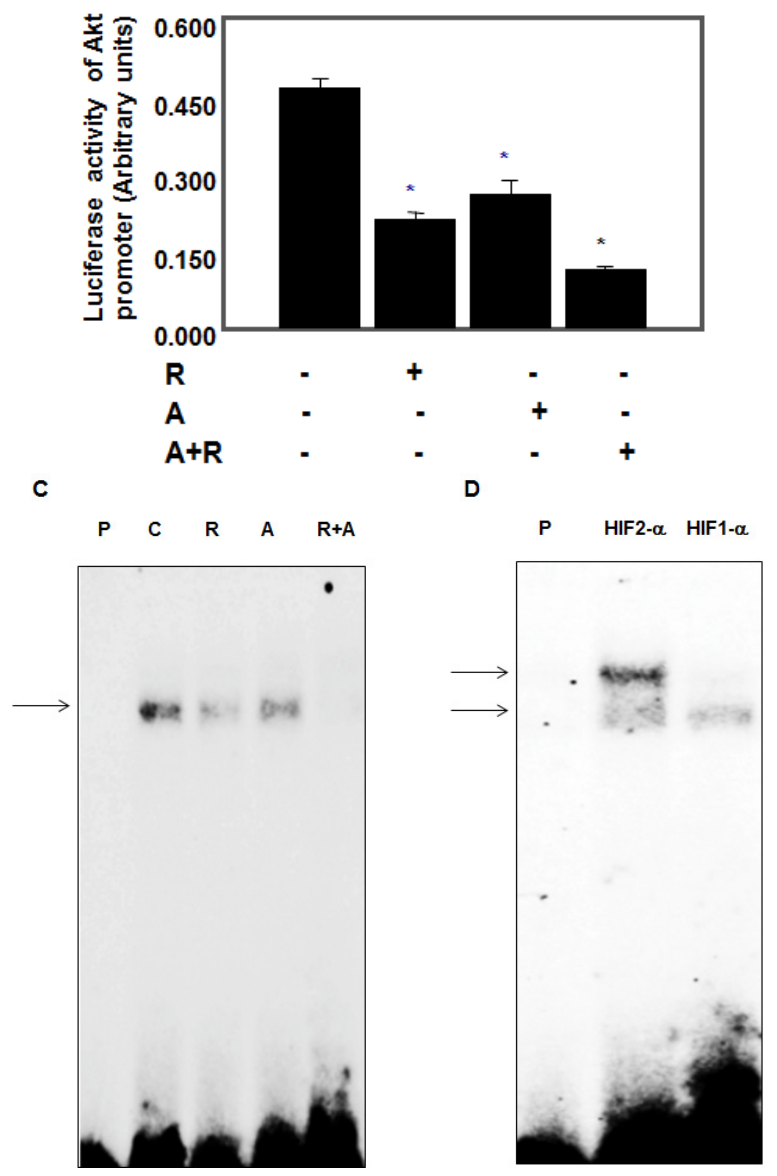

Figure 3: Drug combinations abolished Akt survival kinase and blocked binding of HIF-2 $\alpha$ to Akt promoter in AML cells. Cells were treated with rapamycin $(20 \mathrm{nM})$ or AICAR $(2 \mathrm{mM})$ or drug combinations $(20 \mathrm{nM}$ rap/2 mM AICAR) for $72 \mathrm{hrs}$. Cell lysates were subjected to Western blot analysis to measure p-Akt, HIF-2 $\alpha$ expression. A. Significant decrease in p-Akt, HIF-2 $\alpha$ expression in cells treated with single drug while synergistic effect of drug combinations showed complete abolishment in HIF-2 $\alpha$ as well as in phosphorylation of Akt at $\mathrm{Ser}^{473}$ expression compared to cells treated with single drug and control cells. GADPH was used as a loading control. Further evidence of the effect of drug combinations on HIF- $2 \alpha$ function was measured by luciferase assay. B. The synergistic effect of drug combinations showed more than $70 \%$ decrease in the promoter activity of HIF-2 $\alpha$ compared to control cells using the Luciferase Reporter Assay System normalized by Renilla activity and measured by a luminometer. Data represent means \pm SE $(n=4)$. Significant difference from control cells is indicated by $* P<0.01$. A combination of drugs blocks binding of HIF $2 \alpha$ to the Akt promoter element. C. EMSA analysis of DNA probe corresponding to the putative HIF-2 $\alpha$ binding site in the Akt promoter was performed. Labeled probes were incubated with nuclear extracts isolated from AML cells treated with rapamycin, AICAR or rapamycin+AICAR showed significant decrease in binding of HIF- $2 \alpha$ into the Akt promoter. D. Specificity of binding of HIF- $\alpha$ to Akt promoter was confirmed by adding HIF $1 \alpha$ or HIF- $2 \alpha$ antibody to the reaction mixture. Data confirmed that HIF-2 $\alpha$ not HIF- $1 \alpha$ as a part of DNA-protein complex. These data provide new evidence that HIF2 $\alpha$ is a major transcription factor that regulates cell survival kinase Akt. 
synergistic effect to block activation of Akt survival kinase as well as accumulation of HIF- $2 \alpha$ through activation of AMPK and inhibition of mTORC1.

\section{Drug combinations block binding HIF2 $\alpha$ to Akt promoter in AML cells}

To provide another evidence of the effect of combined drugs on HIF-2 $\alpha$ function, we examined the effect of each drug and drug combinations on binding of HIF- $2 \alpha$ to the putative binding sequence in the Akt promoter using nuclear extracts from AML cells. Nuclear extracts from control or cells treated with $2 \mathrm{mM}$ AICAR or $20 \mathrm{nM}$ rapa or $2-\mathrm{mM} / 20 \mathrm{nM}$ AICAR/rapa were used to perform electrophoretic mobility shift assay (EMSA). Cells treated with single drug show no significant changes compared to control cells while cells treated with both drugs almost abolished the binding of the HIF-2 $\alpha$ to the putative Akt1 promoter (Figure 3C). The specificity of HIF-2 $\alpha$ as a part of DNA-protein complex was tested by pre-incubating the nuclear proteins with HIF $1 \alpha$ or HIF- $2 \alpha$ antibody. Data in Figure 3D show that the DNA/protein

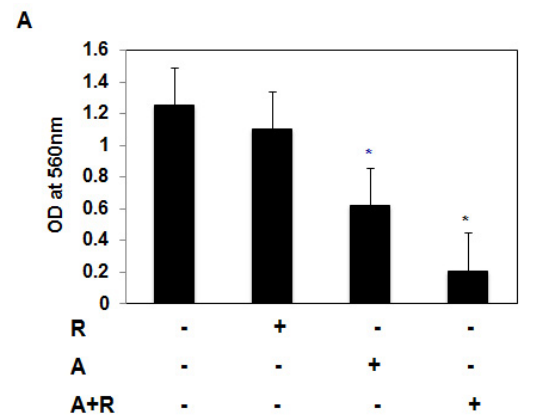

B
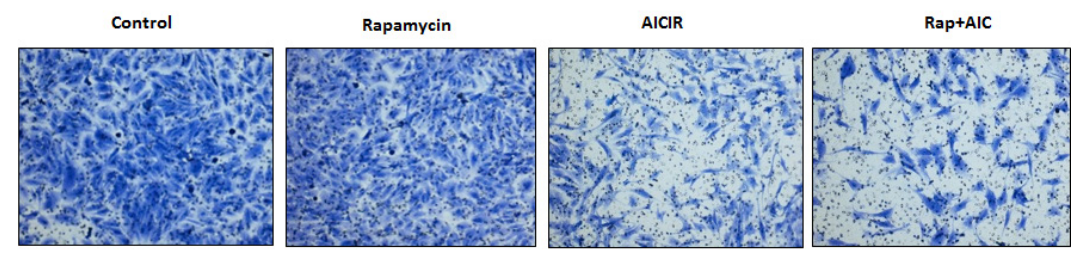

c

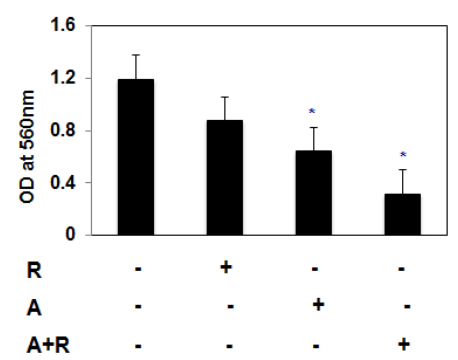

D
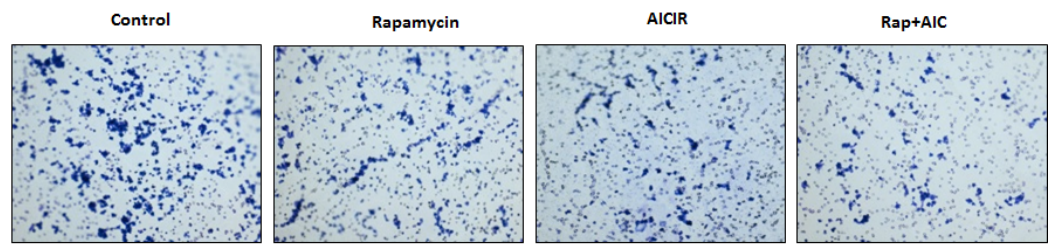

Figure 4: Drug combinations significantly decreased cell migration and cell invasion of AML cells. AML cells treated with rapamycin $(20 \mathrm{nM})$ or AICAR $(2 \mathrm{mM})$ or drug combinations $(20 \mathrm{nM}$ rap $/ 2 \mathrm{mM}$ AICAR) for $72 \mathrm{hrs}$ were added into the upper well chamber of 96-wells plate. Data in A. \& B. show that cells treated with drug combinations has significant low number of migrated cells and C. \& D. invaded cells compared to cells treated with single drug or control cells. The total number of migrated and invaded cells was counted using counting software and the images of migrated or invaded cells were taken using Nikon light inverted microscope. Significant difference from control cells is indicated by $* P<0.01$. 
complex shifted when only HIF-2 $\alpha$ antibody was added in the reaction suggesting that HIF $2 \alpha$ is major transcription factor that binds to Akt promoter to activate cell survival. Taken together, these data provide new evidence that HIF $2 \alpha$ is a major transcription factor that regulates cell survival kinase Akt.

\section{Drug combinations significantly decreased cell migration and cell invasion of AML cells}

It is known AML cells have migration and invasion character to promote metastasis. Next, we tested the effect of each drug or drug combinations on cell invasion and cell migration. AML cells treated with rapamycin $(20 \mathrm{nM})$ or AICAR $(2 \mathrm{mM})$ or drug combinations $(20 \mathrm{nM}$ rap $/ 2 \mathrm{mM}$ AICAR) for $72 \mathrm{hrs}$ showed different patterns of cell migration and invasion. Data in Figure 4A \& 4B show that cells treated with drug combinations has significant low number of migrated cells compared to cells treated with single drug or control cells. We tested whether each drug alone or drug combinations will have more effect on cell invasion. Data in Figure 4C \& 4D show that cells treated

A

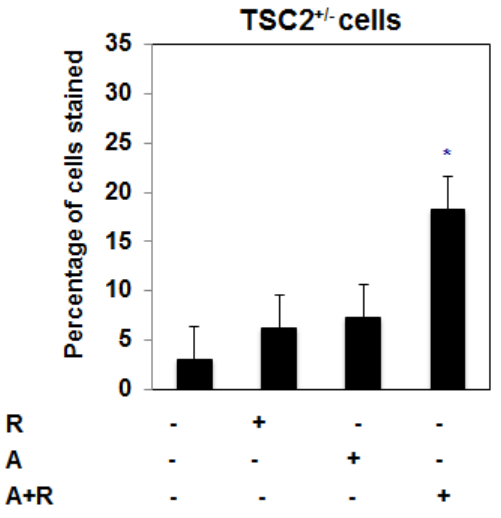

TSC2 $^{+/-}$cells

C

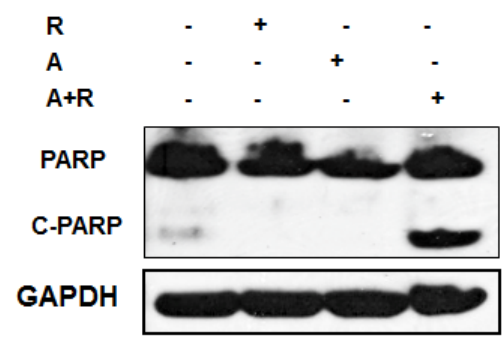

with drug combinations has significant low number of invaded cells compared to cells treated with single drug or control cells. These data suggest that the synergistic effect of the drug combinations on preventing the cells migration and invasion will have important role in preventing tumor metastasis.

Drug combinations significantly increased cell apoptosis in fresh primary $\mathrm{TSC2}^{+/-}$and $\mathrm{TSC}^{-/}$cells isolated from kidney of $\mathrm{TSC2}^{+/-}$mice

We tested the effect of each drug and drug combinations in TSC cells isolated from kidney of TSC mice to provide in vitro evidence before starting in vivo experiment using TSC mice. Fresh primary cells isolated from normal $\left(\mathrm{TSC}^{+/}\right)$and kidney tumor $\left(\mathrm{TSC}^{-/}\right)$tissues of mice were used to confirm the effect of treatment with drug combinations versus single drug alone. Data in Figure $5 \mathrm{~A} \& 5 \mathrm{~B}$ show 6 -fold and 14 fold increase in number of apoptotic cells in $\mathrm{TSC}^{+/-}$and $\mathrm{TSC}^{-/-}$respectively after treatment with combined drugs compared to non-treated cells. In addition, cleavage of apoptotic protein, PARP at

B

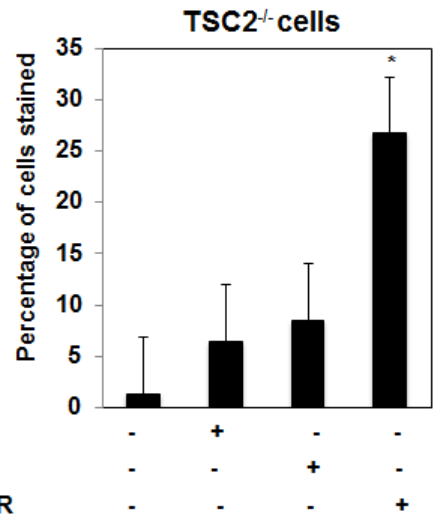

D

TSC2 ${ }^{-1}$ cells

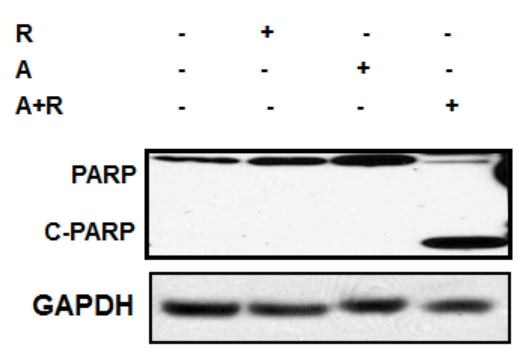

Figure 5: Synergistic effect of drug combinations significantly increased cell apoptosis, decreased cell proliferation, blocked Akt and decreased HIF-2 $\alpha$ expression in primary TSC2 $^{+/-}$and TSC ${ }^{-/}$cells. A. \& B. Single drug treatment (Rap, $20 \mathrm{nM}), \operatorname{AICAR}(20 \mathrm{mM})$ and drug combinations $(2 / 20 \mathrm{mM} / \mathrm{nM})$ show significant increased in number of apoptotic cells in cells treated with drug combinations using annexin V-FITC conjugated to PI by flow cytometry in both primary TSC2 ${ }^{+/}$and TSC ${ }^{-/-}$cells. C. \& D. Lysates from cells treated with rapmycin $(20 \mathrm{nM})$, AICAR $(2 \mathrm{mM}), \operatorname{AICAR}+$ rapamycin $(2 \mathrm{mM} / 20 \mathrm{nM})$ for $72 \mathrm{hrs}$ showed significant increase in cleavage of PARP at $85 \mathrm{KDa}$ in TSC2 $2^{+-}$and TSC $^{-/}$cells treated with drug combinations compared to cells treated with each drug alone. GAPDH was used as a loading control. Data represent means \pm SE $(n=4)$. Significant difference from control cells is indicated by $* P<0.01$. 
$85 \mathrm{kDa}$ was significantly increased in treated cells with drug combinations compared to cells treated with each drug alone for $72 \mathrm{hrs}$ (Figure 5C \& 5D). These data suggest that drug combinations are more effective than single drug in increasing number of apoptotic cells.

\section{Drug combinations significantly decreased cell proliferation in fresh primary $\mathrm{TSC2}^{+/-}$and $\mathrm{TSC}^{-/-}$ cells isolated from kidney of $\mathrm{TSC}^{+/-}$mice}

The synergistic effect of drug combinations and each drug treatment on reducing cell proliferation was tested in fresh primary cells of $\mathrm{TSC}^{+/-}$and $\mathrm{TSC}^{-/-}$mice. Data in Figure $6 \mathrm{~A} \& 6 \mathrm{~B}$ show that drug combinations treatment resulted in 5 fold and 6 fold decrease in cell proliferation in $\mathrm{TSC}^{+/-}$and $\mathrm{TSC}^{-/-}$respectively compared to non-treated cells. In addition, abolishment of expression of PCNA in $\mathrm{TSC}^{+/-}$cells treated with drug combinations compared

A

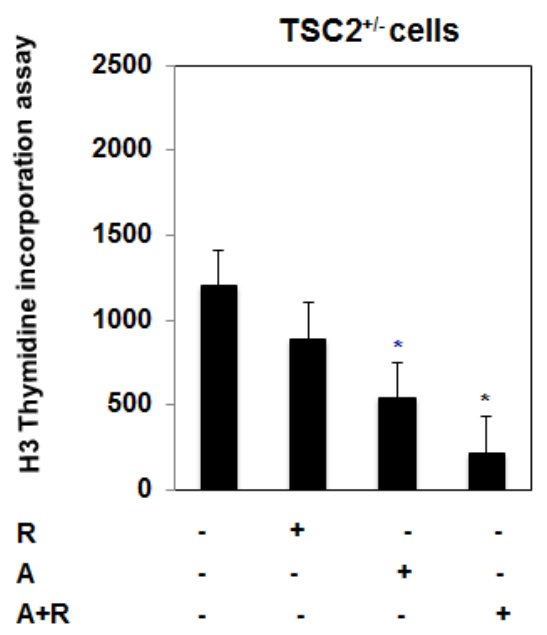

C

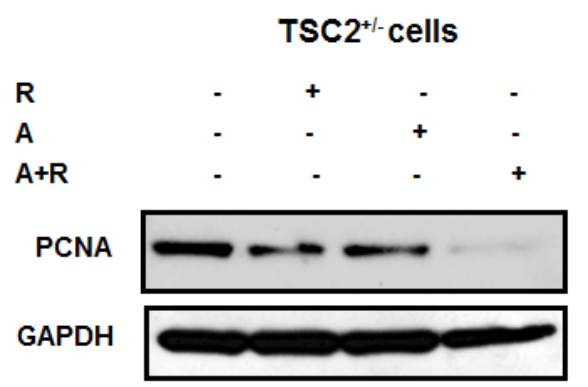

to non-treated cells or single drug treatment (Figure 6C). While significant decrease in PCNA was observed in $\mathrm{TSC}^{-/-}$cells treated with drug combinations (Figure $6 \mathrm{D})$. These data suggest that drug combinations are more effective on slowing tumor progression by decreasing cell proliferation and increasing cell apoptosis.

Synergistic effect of drug combinations abolished Akt phosphorylation and HIF2 $\alpha$ expression in fresh primary $\mathrm{TSC2}^{+/-}$and $\mathrm{TSC}^{-/-}$cells isolated from kidney of $\mathrm{TSC2}^{+/-}$mice

Abolishment of Akt phosphorylation at $\mathrm{Ser} 4^{73}$ expression was detected in $\mathrm{TSC}^{+/-}$and $\mathrm{TSC}^{-/-}$cells treated with drug combinations compared to cells treated with single drug and control cells (Figure 7A-7D). In addition, rapamycin and AICAR significantly decreased phosphorylation of Akt and HIF2 $\alpha$ expression compared

B

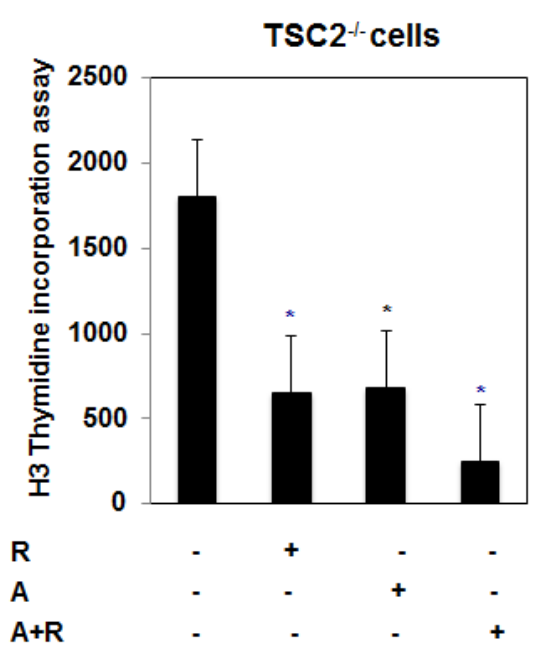

D

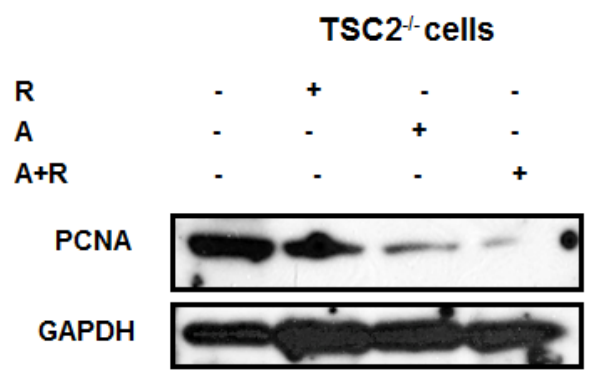

Figure 6: Decrease in cell proliferation by drug combinations is dependent on the drug concentration and duration of exposure in primary TSC2 ${ }^{+-}$and TSC $^{-/-}$cells. A. \& B. Single drug treatment (Rap, 20nM), AICAR (20mM) and drug combinations $(2 / 20 \mathrm{mM} / \mathrm{nM})$ showed significant decrease in cell proliferation using ${ }^{3} \mathrm{H}$-thymidine incorporation assay in both primary TSC2 ${ }^{+/}$and $\mathrm{TSC}^{-/}$cells. Cell proliferation data was confirmed by measuring proliferative protein expression. Lysates from cells treated with rapmycin $(20 \mathrm{nM})$, AICAR $(2 \mathrm{mM})$, rapamycin+AICAR $(20 \mathrm{nM} / 2 \mathrm{mM})$ for $72 \mathrm{hrs}$ were subjected to Western blot analysis to measure PCNA and cyclin D1. C. \& D. Significant decrease in expression of PCNA was detected in cells treated with single drug while abolishment of expression of both proteins detected in cells treated with drug combinations providing evidence of the synergistic effect of drug combinations in reducing cell proliferation. GAPDH was used as a loading control. Data represent means $\pm \mathrm{SE}(n=4)$. Significant difference from control cells is indicated by $* P<0.01$. 
to non-treated $\mathrm{TSC}^{+/-}$and $\mathrm{TSC}^{-/-}$cells (Figure 7A-7D). Moreover, the effect of each drug or drug combinations on Akt promoter activity was tested in $\mathrm{TSC}^{+/}$and $\mathrm{TSC}^{-}$ - primary cells. Data in Figure 7E \& 7F show significant decrease in Akt promoter activity measured by luciferase compared to non-treated cells, while sharp decrease in Akt promoter activity was observed in cells treated with drug combinations in $\mathrm{TSC}^{+/-}$and $\mathrm{TSC}^{-/-}$cells (Figure 7E \& 7F). These data provide a new evidence of synergistic effect of drug combinations on blocking AKT/HIF-2 pathway to decrease tumor progression. These data also provide strong evidence that drug combinations will be more effective than each drug alone to treat $\mathrm{TSC}^{+/-}$mice.
A

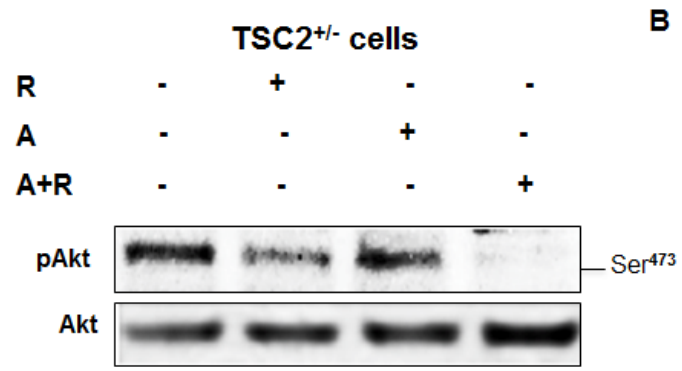

C
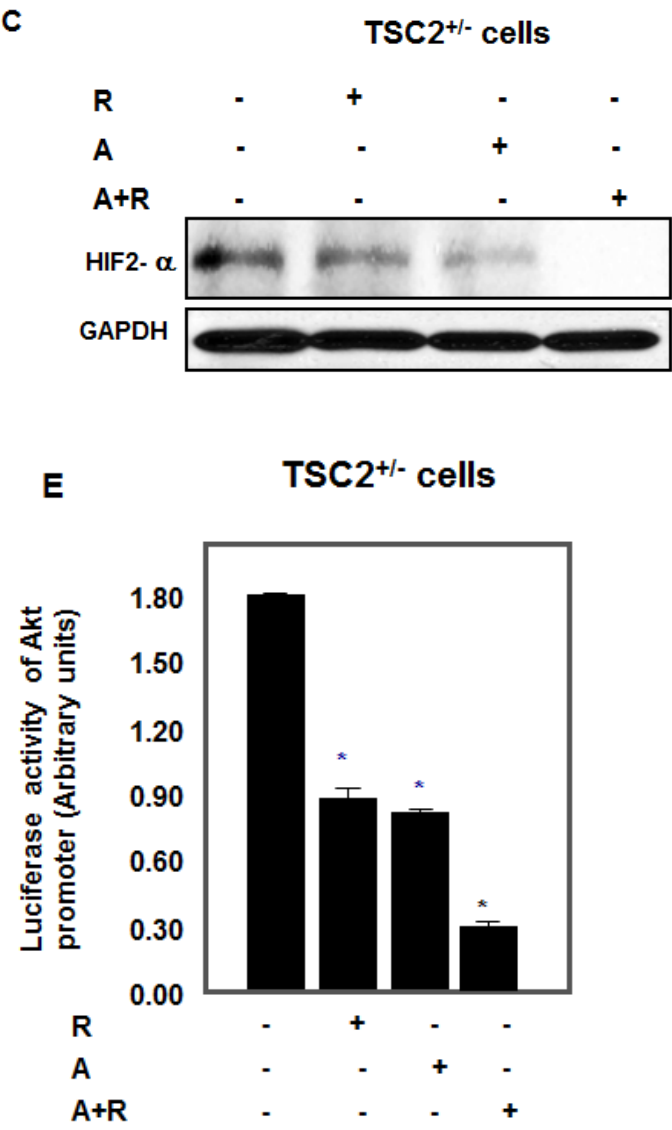

B

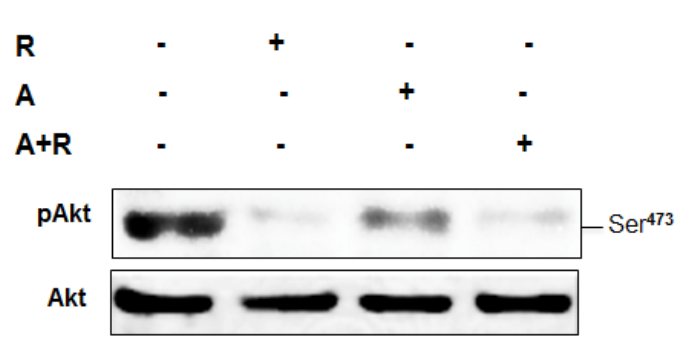

D

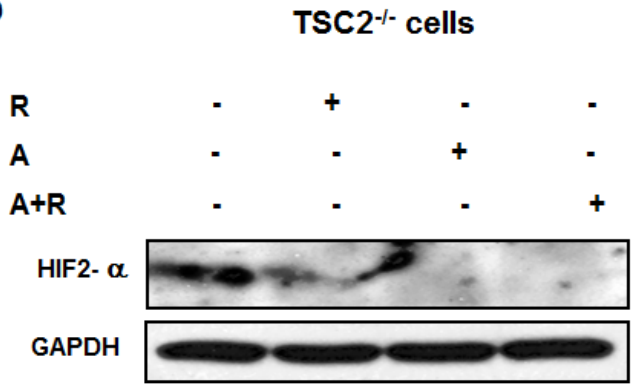

$\mathbf{F}$

TSC2 $^{-/-}$cells

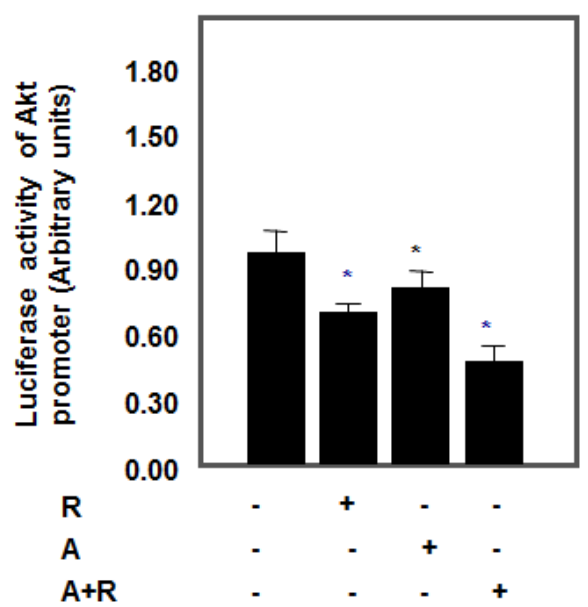

Figure 7: Abolished p-Akt and HIF-2 $\alpha$ expression in cells treated with drug combinations. A.-D. TSC2 $2^{+/}$and TSC ${ }^{-/}$cell extracts of treated cells with single drug or drug combinations were subjected to Western blot analysis. Abolished phosphorylation of Akt at $\mathrm{Ser}^{473}$ and HIF-2 $\alpha$ protein expression in TSC2 $2^{+-}$cells and significant decrease in p-Akt and HIF-2 $\alpha$ expression in TSC $\mathrm{TC}^{-/}$cells compared to non-treated cells. GADPH was used as a loading control. E. \& F. The synergistic effect of drug combinations showed more than $84 \%$ and $50 \%$ decrease in the promoter activity of HIF- $2 \alpha$ in TSC2 ${ }^{+-}$and $\mathrm{TSC}^{-/-}$cells compared to control cells. The Luciferase Reporter Assay was normalized by Renilla activity and measured by a luminometer. Data represent means $\pm \mathrm{SE}(n=4)$. Significant difference from control cells is indicated by $* P<0.01$. 
No toxicity in kidney of $\mathrm{TSC2}^{+/-}$mice treated with single drug or drug combinations

To test the side effect of drug toxicity on animals during the injection, urinary and serum excretion of glutathione-S-transferase (GST) as an indicator of the loss of cell membrane integrity animal was determined in all 4 experimental groups. Urine was collected a day before sacrificing the mice and serum collected during sacrificing the mice. Data in Figure 8A \& 8B show that no significant changes in the levels of urine and serum of GST activity between mice treated with single drug or drug combinations compared to control group of mice. Only AICAR treatment shows increase in serum GST compared to control and other groups. These data provide new evidence of the safety of drug combinations as a novel direction for future treatment of kidney cancer.

\section{Drug combinations are more effective on reducing tumor size and number in $\mathrm{TSC}^{+-}$mice}

We further investigated the synergistic effect of drug combinations on reducing kidney tumor size in vivo. $\mathrm{TSC}^{+/-}$mice at age of 12 months were divided to 4 groups, control (mice were injected with an equal amount of DMSO). Group 2, (mice injected with $2 \mathrm{mg} / \mathrm{kg}$ body weight rapamycin), group 3 (mice injected with $250 \mathrm{mg} /$ $\mathrm{kg}$ body weight AICAR) and group 4 (mice injected with same doses of rapamycin $(2 \mathrm{mg} / \mathrm{kg})$ and AICAR
$(250 \mathrm{mg} / \mathrm{kg})$. Animals were euthanized after treatment and kidneys were removed rapidly to measure tumor size by two independent observers blinded to the experimental conditions. Image of kidney from all 4 groups of mice in Figure 9A show the differences in tumor sizes within 4 groups of mice. Data in Figure 9B show that treatment with rapamycin resulted in significant decrease in cysts number, $25 \%$ decrease in tumor number and $27 \%$ decrease in tumor volume compared to control mice. AICAR treatment showed $50 \%$ decrease in tumor number and $43 \%$ in tumor volume compared to non-treated group. Major finding from our study that treatment with drug combinations resulted in $75 \%$ decrease in tumor number and $88 \%$ decrease in tumor volume compared to nontreated mice. These data provide a novel role of drug combinations on decreasing tumor size and number and will be helpful to develop a clinical trail study in TSC patients.

\section{Drug combinations are more effective to block cell proliferation and increase cell apoptosis in kidney tumor}

H\&E staining showed the size and histology of tumor in kidney sections from 4 groups of mice (Figure 10A). TUNEL assay was performed in kidney sections from each mouse to test the effect of treatment with single drug versus drug combinations of cell apoptosis. Kidney sections were examined using light microscopy
A

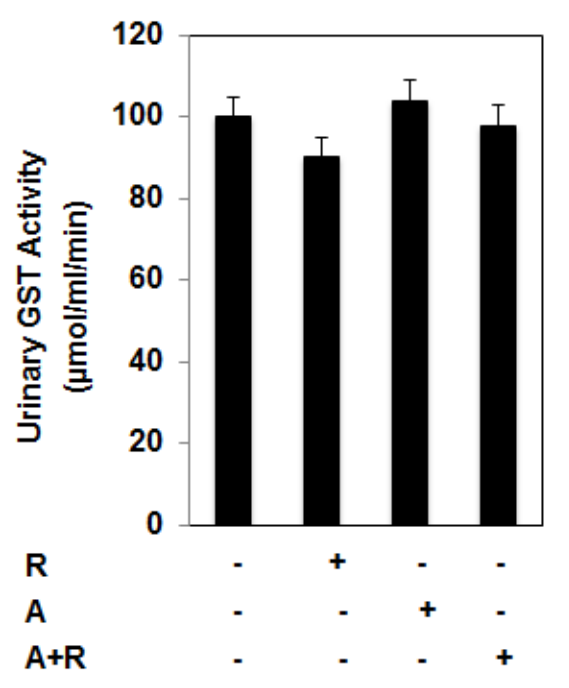

B

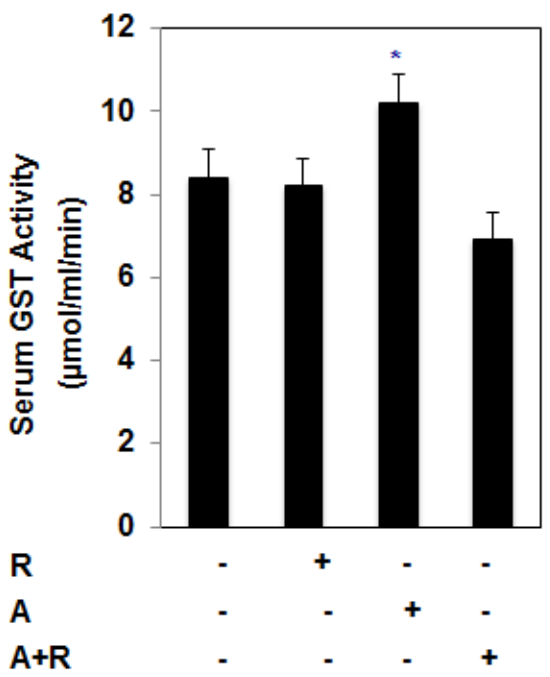

Figure 8: Drugs alone and in combination show no nephrotxoicity in treated mice. Renal injury was determined by measuring the A., urinary and B., serum excretion of GST in mice following treatment with rapamycin or AICAR or combination of rap + AIC for 4 weeks. AICAR treatment showed slight increase in GST activity in serum but not major changes between 4 groups of mice indicating no toxicity of treatment with single drug or drug combinations. Values represent the mean $\pm \mathrm{SE}(n=6)$ and GST activity represent as $\mu$ mol/ $\mathrm{ml} / \mathrm{min}$. Significant difference from control mice is indicated by $* P<0.01$. 
and number of apoptotic cells in mice treated with drug combinations and less in group treated with single drug compared to control mice group (Figure 10B). These data was confirmed in tumor kidney homogenates from all 4 mice groups. Strong cleavage in PARP at $85 \mathrm{kDa}$ in mice treated with drug combinations compared to mice treated with single drug and control mice group (Figure 10C). On the other hand, cell proliferation staining using Ki67 proliferative marker was performed in kidney sections from each group of mice. Data in Figure 10D show significant decrease in number of stained nucleus with Ki67 in kidney tumor mice treated with drug combinations and less in mice treated with single drug compared to control mice group. These data was also confirmed in tumor kidney homogenates from all 4 groups using proliferative protein markers (cyclin D1) by Western blot analysis. Data in Figure 10E show that drug combinations have strong effect in decreasing cyclin D1 expression compared to mice treated with single drug and control mice group. These data suggest that the synergistic effect of drug combinations have strong impact to slow the progression of tumor by decreasing cell proliferation and increasing cell apoptosis.

\section{Drug combinations has strong effect on inhibiting cell survival kinase and decreasing HIF-2 $\alpha$ expression}

Akt is the major cell survival kinase therefore identifying a $\operatorname{drug}(\mathrm{s})$ can slow cancer cell survival

A
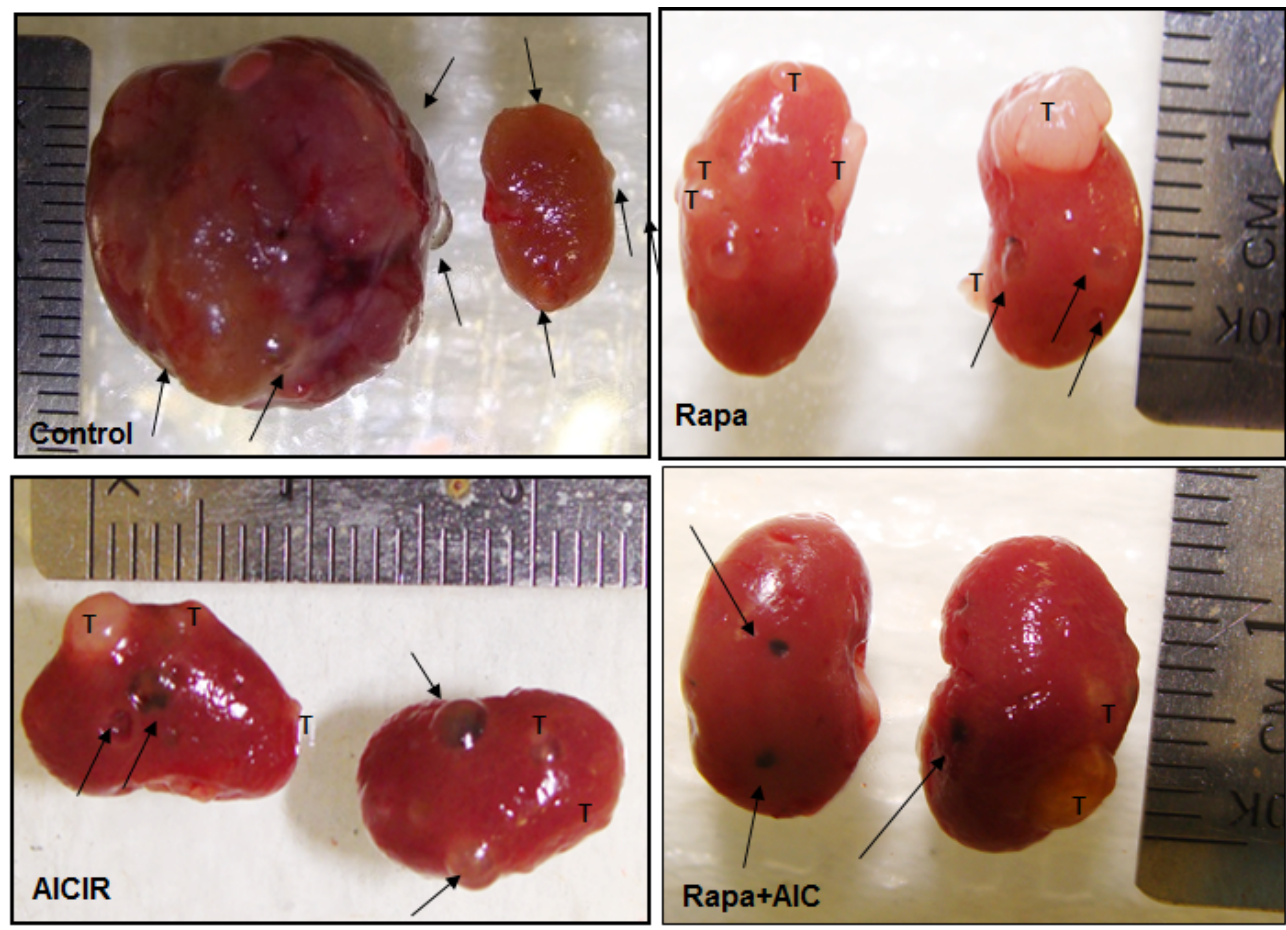

B

Combinations of drug significantly reduced the number and size of tumors in $\mathrm{TSC}^{+/-}$mice

\begin{tabular}{|l|c|c|c|c|}
\hline & Control & Rapa & AICAR & Rap+AIC \\
\hline Total number of cysts & 29 & 21 & 22 & 13 \\
\hline Total number of tumors & 8 & 6 & 4 & 2 \\
\hline$\%$ decrease in tumor number & & -25 & -50 & -75 \\
\hline Total tumor Volume (cm ${ }^{\text {) }}$ & 0.863 & 0.63 & 0.49 & 0.1 \\
\hline$\%$ decrease in tumor volume & & $-27^{*}$ & $-43^{*}$ & $-88^{*}$ \\
\hline
\end{tabular}

Figure 9: Synergistic effect of drug combinations resulted in significant decrease in kidney tumor size and number in TSC2 $^{+/}$mice. A. Macroscopic view of all mice kidneys was examined for cysts, number and size of tumors. Tumor size was measured in three axes as $\mathrm{cm}^{3}$ (length, width, and height). B. Treatment with rapamycin resulted in significant decrease in cysts number, $25 \%$ decrease in tumor number and $27 \%$ decrease in tumor volume compared to control mice. AICAR treatment showed $50 \%$ decrease in tumor number and $43 \%$ in tumor volume compared to non-treated group. Major decrease in tumor size and number was noticed in mice treated with drug combinations and resulted in $75 \%$ decrease in tumor number and $88 \%$ decrease in tumor volume compared to non-treated mice. Cysts marked with arrow and tumor marked with T. Significant difference from control mice is indicated by $*<0.01$. 


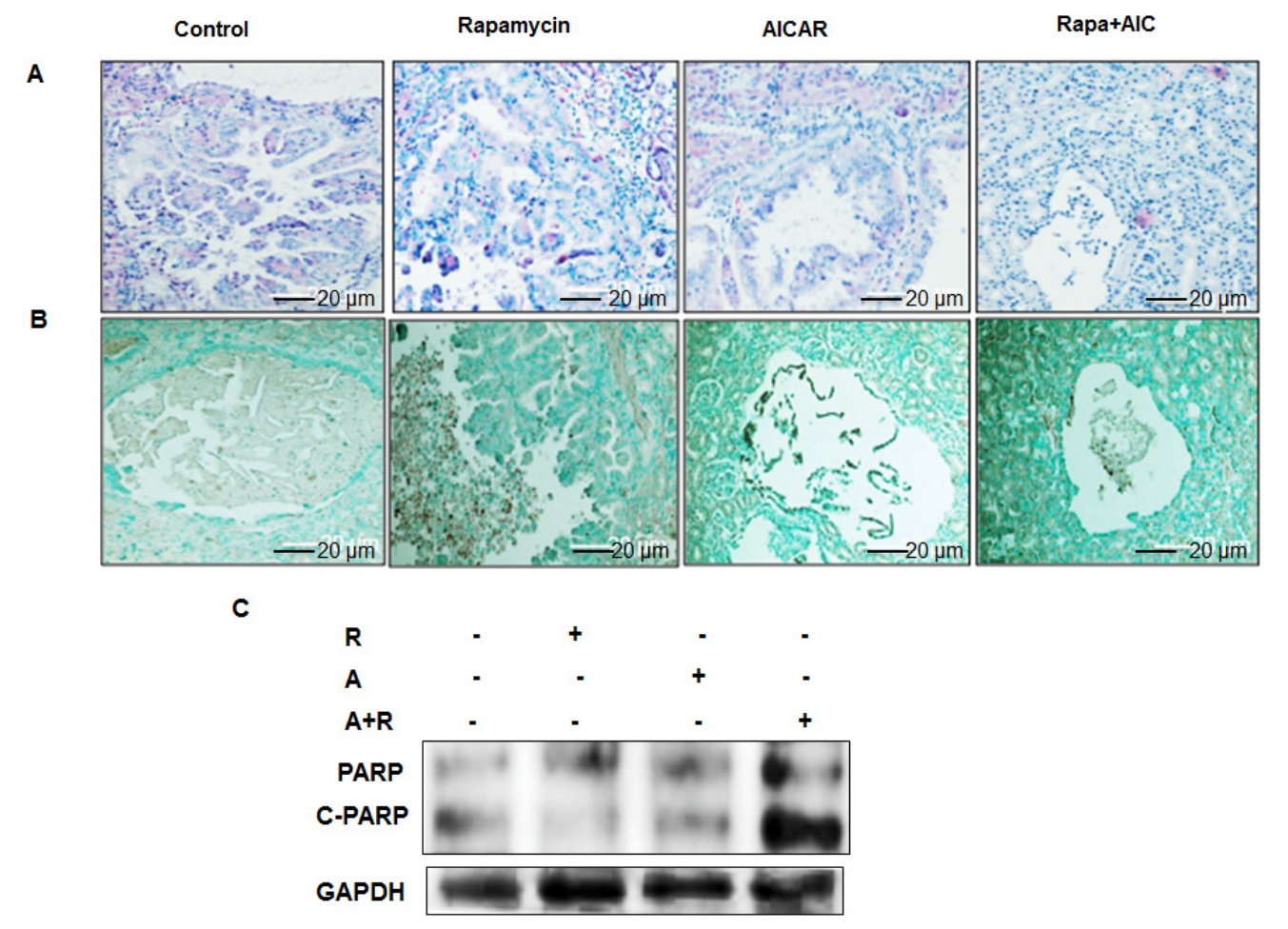

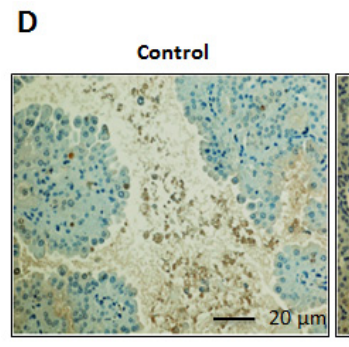

E

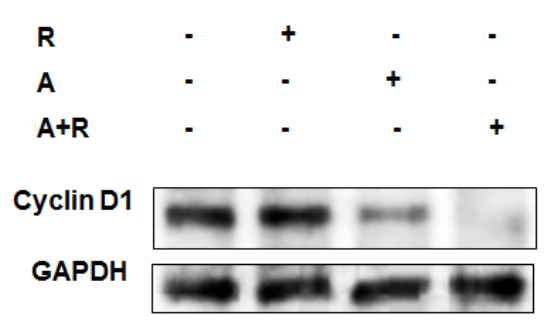

Rapamycin

AICAR

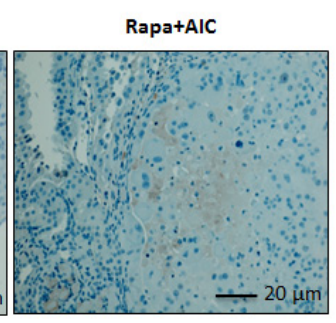

F

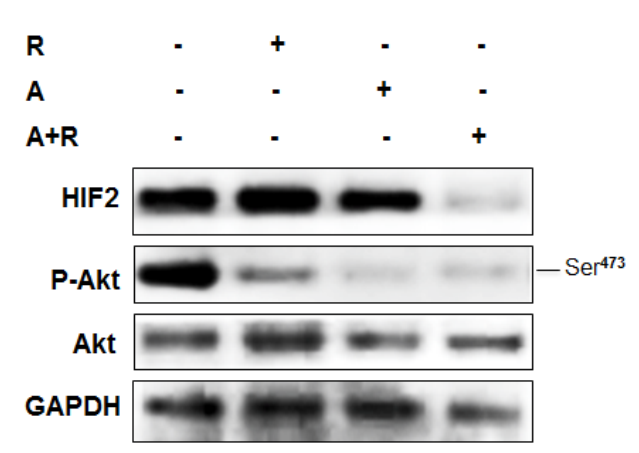

Figure 10: Synergistic effect of drug combinations strongly increased cell apoptosis, decreased cell proliferation and decreased p-Akt/HIF-2 $\alpha$ expression. TUNEL assay was performed in kidney sections of 4 groups of mice and pictures taken by light microscope. A. H\&E staining of kidney from all 4 groups of mice show the differences in tumor sizes within 4 groups of mice. B. Stained nucleus for TUNEL show significant increase in number positive cells in mice treated with drug combinations and less in mice treated with single drug compared to control mice group. In addition, tumor kidney homogenates from all 4 mice groups was subjected to Western blot analysis. C. Apoptosis proteins including cleavage of PARP was measured in kidney sections of mice treated with drug combinations and mice treated with single drug and control mice group. D. Proliferative proteins expression of Ki67 showed that drug combinations significantly decrease Ki67 staining in nucleus in kidney tumor compared to tumor from mice treated with single drug and control mice group. E. Western blot analysis was performed in tumor homogenates from 4 groups of mice show significant decrease in cyclin D1 in mice treated with drug combinations compared to mice treated with single drug and control mice group. F. Data of Western blot showed that drug combinations nearly abolished p-Akt and significantly decreased expression of HIF-2 protein expression in tumor tissues compared to tumor from mice tested with single drug and control mice group. 
will be important to control tumor progression. In addition, hyperactivation of HIF- $1 / 2 \alpha$ is a key factor in tumorigenesis. Tumor tissue homogenates from all 4 groups of mice were subjected to Western blot analysis. Data in Figure 10F show that P-Akt at Ser ${ }^{473}$ and HIF-2 $\alpha$ expression is significantly decreased in mice treated with drug combinations compared to mice treated with single drug and control mice group. Taken together these data provided a strong evidence of the synergistic effect of drug combinations on reducing tumor progression in TSC mice through regulation cell apoptosis and cell proliferation pathways.

\section{DISCUSSION}

Rapmaycin has been used for treatment several types of cancer and AICAR have been approved in clinical studies but no clinical trial registered for using combination of both drugs for treatment of TSC patients. Our data tested the synergistic effect of the combination of rapamycin+AICAR for treatment of kidney tumorigenesis in AML human and in $\mathrm{TSC}^{+/-}$and $\mathrm{TSC}^{-/-}$ fresh tubular cells isolated from normal and tumor kidney of $\mathrm{TSC}^{+/-}$mouse and in $\mathrm{TSC}^{+/-}$mouse model. Drug combinations have strong synergistic effect to decrease cell proliferation, increase cell apoptosis and abolish Akt/ HIF $2 \alpha$ expression in AML, TSC $2^{+/-}$and $\mathrm{TSC}^{-/-}$cells. We have identified a putative HIF- $1 / 2 \alpha$ binding site in the Akt1 promoter. In addition, drug combinations effectively abolished the binding of HIF-2 $\alpha$ to the putative Akt1 promoter providing new evidence that HIF-2 $\alpha$ is a major transcription factor involved in activation cell survival kinase (Akt). Importantly, the synergistic effect of the drug combinations shows important influence on decreasing cells migration and invasion compared to single drug treatment suggesting that combined drugs has a major effect in preventing tumor progression and metastasis. Our major in vivo data finding that treatment of TSC mice with drug combinations resulted in $75 \%$ decrease in tumor number and $88 \%$ decrease in tumor volume compared to control TSC mice.

One of the major anticancer drugs side effects is drug toxicity to kidney. Data from injection of single drug or drug combinations into mice for 4 weeks did not show any significant changes in the levels of GST activity as an indicator of early marker for renal dysfunction [25] in mice treated with single drug or drug combinations compared to control mice group suggesting that drug combinations may be useful for future treatment of TSC patients. Drug combinations shows significant increase in cell apoptosis, decrease in cell proliferation, sharp decrease in survival kinase (Akt) and decrease in major transcription factor HIF-2 $\alpha$ in tumor tissues compare to single drug and control mice group.

The mammalian target of rapamycin (mTOR) plays a central role in regulating cell growth, proliferation and survival, in part by the regulation of translation initiation [28-30]. In addition, mTOR signaling pathways are constitutively activated in many types of human cancer [30]. It is known that mTORC2 promotes activation of the cell survival protein by phosphorylation of Akt at residues $\mathrm{Ser}^{473}$ and other growth factors [9]. Targeting mTOR is emerging as an important approach in cancer therapeutics. Early clinical trials show that kidney tumours regress in response to treatment with rapamycin and other mTOR inhibitor including everolimus, a direct-target of inhibition of mTORC1 [31, 32]. In addition, activation AMPK by AICAR show significant increase in cell apoptosis and decrease in cell proliferation by targeting Akt/HIF2- $\alpha$ in $\mathrm{AML}, \mathrm{TSC}^{+/-}$and $\mathrm{TSC}^{-/-}$cells.

AMPK has been recognized as an important upstream signaling intermediate intimately involved in the regulation of the mTOR pathway. Our data show that AICAR has significant effect in reducing HIF$2 \alpha$ and cell invasion of AML cells compared to control cells. Our previous data show that activation of AMPK by AICAR results in decreased p70S6K phosphorylation and increased DNA repair expression protein OGG1 expression and rapamycin activates AMPK leading to increased OGG1 protein expression in renal cancer cells [17]. in vivo and in vitro observation showed that blocking mTOR1 and $\mathrm{mTORC} 2$ activation results in prevention of tumor progression in $\mathrm{TSC}^{+/}$mice. In accordance with our data, similar recent findings show that new mTOR kinase inhibitor (WYE-687) increased apoptosis and blocked activation of both mTORC1 and $\mathrm{mTORC} 2$ through the feedback activation of p-Akt in renal cancer cells as well as the oral administration of WYE-687 potently suppressed tumor growth in nude mice injected with renal cancer cells [33]. These findings suggest that suppressing the HIF-2 may be an important therapeutic strategy for the treatment of tumorigenesis in TSC patients. Our data show that blocking mTORC1 by rapamycin increases cell apoptosis and significantly decreases cell proliferation targeting Akt/HIF2- $\alpha$ pathway to influence number of migrated and invaded AML cells. Major finding of our work show that treatment of the mice with drug combinations resulted in $75 \%$ decrease in tumor number and $88 \%$ decrease in tumor size compared rapamycin $(25 \%$ in tumor number and $27 \%$ in tumor size) and AICAR (50\% decrease in tumor number and $43 \%$ decrease in tumor size) suggesting that the drug combinations are more effective in reducing tumor size compared to each drug alone. For our knowledge, there is none clinical studies of AMPK activator (AICAR or metformin) that used for TSC-associated AML but AICAR or metformin have been used in clinical trial for kidney cancer. Data from our study provided the first evidence of novel approach of the effective of drug combination of AICAR+Rapamycin on blocking tumorigenesis in TSC-animal model and also the safety of using drug combinations without any toxicity in kidney.

In summary, we showed that single and combined 
drugs have no significant effect on the body weight and no toxicity to the kidney of TSC 2 mice. Treatment with drug combinations has strong effect in inhibiting cell proliferation and increasing cell apoptosis to block cell survival kinase (Akt) and abolish HIF-2 expression in $\mathrm{AML}, \mathrm{TSC}^{+/-}$and $\mathrm{TSC}^{-/-}$cells and in $\mathrm{TSC}^{+/-}$mouse model. Major finding of our work is that low dose of drug combinations reduced $88 \%$ of kidney tumor size compared to control mice and these finding provide a new evidence of the strong effect of drug combinations in reducing kidney tuomorigenesis. Taken together in vitro and in vivo data show new finding of the role of drug combinations in reducing kidney tumor progression in TSC mouse and new evidence that drug combinations has more benefit to treat TSC patients than single drug alone. Our data provided a new mechanism of preventing kidney tumor progression without side effect of drug combinations in the treated mice. These data provide in vivo evidence to initiate a clinical trail for treatment of TSC patients with kidney tumors.

\section{MATERIALS AND METHODS}

\section{Cell culture}

Angiomyolipoma (AML) cells derived from human kidney of TSC patient were generously provided by Dr. Elizabeth Henske (Harvard Medical School, MA) [18]. Mouse tubular cells were isolated from normal ( $\mathrm{TSC2}^{+-}$) and tumor $\left(\mathrm{TSC}^{-/}\right)$kidney mouse and cultured as previously described [19]. AML, TSC2 $2^{-/}$and $\mathrm{TSC}^{+/-}$cells were grown in DMEM supplemented with $10 \%$ FBS at $37^{\circ} \mathrm{C}$ in a humidified atmosphere of $5 \% \mathrm{CO}_{2}$.

\section{Cells treatment}

AML cells were treated with serial concentrations of $\operatorname{AICAR}(0,2,4,10 \mathrm{mM})$ [16] or rapamycin $(0,20,40$, $100 \mathrm{nM})$ [17] or combination of AICAR and rapamycin (0/0, 2/20, 4/40, 10/100 mM/nM, AICAR/rapamycin) for $72 \mathrm{hrs}$. Cells were also treated with drug combinations (2 $\mathrm{mM} / 20 \mathrm{nM}$, AICAR/Rapa) for 24, 48 and $72 \mathrm{hrs}$. AICAR was obtained from Cayman Chemical (Ann Arbor, MI) and rapamycin from Sigma-Aldrich (St. Louis, MO).

\section{Thymidine assay}

Cell proliferation was measured using ${ }^{3} \mathrm{H}$-thymidine incorporation assay. Cells were plated into 24-well dish and treated with serial concentrations of rapamycin or AICAR or drug combinations as described above for $72 \mathrm{hrs}$. At the time of treatment, cells were pulsed with ${ }^{3} \mathrm{H}$ thymidine. After the treatment period, medium was removed and the cells were fixed in 5\% TCA for $10 \mathrm{~min}$. Cells were then washed twice in 5\% TCA for 10 min each at room temperature to remove unincorporated thymidine. Cells were lysed in $750 \mu \mathrm{l}$ of $0.25 \mathrm{~N} \mathrm{NaOH}$ and $0.1 \%$ SDS. The cell lysates $(500 \mu \mathrm{l})$ were transferred into vials containing $5 \mathrm{ml}$ scintillation solution and $50 \mu \mathrm{l}$ of $6 \mathrm{~N} \mathrm{HCl}$. ${ }^{3} \mathrm{H}$-thymidne incorporated was counted in a scintillation counter.

\section{Annexin V assay}

Apoptosis was detected using Annexin V-FITC detection kit (EMD Millipore, San Diego, CA) as previously described [20]. Briefly, cells were trypsinized, counted using hemocytometer, and 200,000 cells were taken for assay. Cells were centrifuged at $1000 \mathrm{Xg}$ for 5 min, washed in PBS, suspended in $400 \mu$ of $1 \mathrm{X}$ binding buffer containing $1.25 \mu \mathrm{l}$ of Annexin V-FITC. Cells were incubated for $20 \mathrm{~min}$ at room temperature in dark. After incubation, cells were centrifuged, suspended in 400 $\mu \mathrm{l}$ of $1 \mathrm{X}$ binding buffer containing $10 \mu \mathrm{l}$ of propidium iodide and incubated for $10 \mathrm{~min}$ in dark. Apoptotic cells were analyzed by flow cytometry (Becton-Dickinson, Rutherford, NJ).

\section{Western blot analysis}

Cell and tissue lysates were prepared in RIPA lysis buffer using a dounce homogenizer as previously described [21]. Protein concentration was determined using Bradford reagent [22]. An aliquot of 30 to $50 \mu \mathrm{l}$ of lysate was electrophoresd on a SDS-polyacrylamide gel. Western blotting was carried out as previously described [21]. Phospho-Akt at Ser ${ }^{473}$, Akt, PCNA, cyclin D1, HIF1/2- $\alpha$ and Caspase 3 antibodies were purchased from Cell Signaling Technology (Danvers, MA); PARP and GADPH antibodies were obtained from Santa Cruz Biotechnology. Expression of each protein was quantified by densitometry using National Institutes of Health image 1.62 software and normalized to a loading control.

\section{Generation of Akt promoter-luciferase reporter plasmid}

The Akt promoter region (-1 to -1991$)$ containing a potential binding HIF-2 $\alpha$ site was cloned into luciferase reporter vector (pGL3). The primers used were: Forward primer: 5'-GGTGCCCGAAGCTTCCGCGACGCT-3', Reverse primer: 5'GGCCACAGAGCTCCTCAGCAGTCCCAG-3'.

Act promoter reporter plasmid was used to determine the transcriptional activity of the HIF-2 $\alpha$ gene [23]. A Renville reporter plasmid (pRL-null) was used as transfection control. Plasmids were transfected into cells 
using the Lipofectamine and Plus Reagent method (Life Technologies, NY). Cells were pre-treated with rapamycin $(20 \mathrm{nM})$ or AICAR $(20 \mathrm{mM})$ or rapamycin+AICAR. Forty-eight hours after transfection, cells were harvested and luciferase activity was measured using DualLuciferase Reporter assay kit (Promega, Madison, WI) and normalized to Renilla activity.

\section{Electrophoretic mobility shift assays (EMSAs)}

Nuclear proteins were prepared from AML cells using nuclear and cytoplasmic extraction kits (Pierce, IL). The protein concentration was determined using the Bradford reagent [22]. EMSA binding reactions were performed as previously described [24]. The oligonucleotides (Akt promoter from -110 to -61 containing Hif $2 \alpha$ binding site) were used as forward primer: 5'-CCCCCAGGCACGTGCAGTGGGTCT-3' and reverse primer: 5'- AGACCCACTGCACGTGCCTGGGGG-3'. The double stranded oligonucleotiudes were endlabeled, and twenty fmol of labeled probe was incubated with the nuclear extracts and $1 \mu \mathrm{g}$ of poly $(\mathrm{dI}-\mathrm{dC}) \cdot(\mathrm{dI}-$ $\mathrm{dC}$ ). To test the specificity of HIF $1 / 2 \alpha$ binding to Akt promoter, $5 \mu \mathrm{l}$ of HIF- $1 \alpha$ or HIF- $2 \alpha$ antibody (Cell Signaling Technology, Danvers, MA) was pre-incubated with nuclear extracts. The binding reaction was carried out at room temperature for $15 \mathrm{~min}$ prior to adding the radiolabeled probe. Competition binding was performed in the presence of a 100-fold excess of the unlabeled oligonucleotide. The complexes were resolved using a 5\% non-denaturing polyacrylamide gel. The gels were dried and autoradigraphed.

\section{Migration and invasion assays}

Migration and invasion assay was performed using 24-well dish with the inserts (Millipore, MS). AML cells were seeded into upper chamber and treated with rapamycin $(20 \mathrm{nM})$ or AICAR $(2 \mathrm{mM})$ or drug combinations ( $20 \mathrm{nM}$ rap/2 mM AICAR) for $72 \mathrm{hrs}$. The lower chamber was filled with DMEM medium. Following $72 \mathrm{hrs}$ of incubation, each well was washed with PBS and the cells were stained with $0.1 \%$ crystal violet solution for $15 \mathrm{~min}$. Following staining; the cells were thoroughly washed in water and air-dried. The total number of migrated and invaded cells was counted using counting software and the images of migrated or invaded cells were taken using Nikon light inverted microscope.

\section{Animals}

\section{$\mathrm{TSC2}^{+/-}$mice}

$\mathrm{TSC}^{+/-}$mice were generously provided by $\mathrm{Dr}$. David J Kwiatkowski (Harvard Medical School, MA). The animals were allowed food and water ad libitum prior to and during the experiments. Mice at 12 months old mice were divided into four groups, each group containing four mice. Group 1 (control), mice were injected with an equal amount of DMSO. Group 2, mice were injected with 2-mg/kg-body weight rapamycin in DMSO 5 days/ week for 4 weeks [17]. Group 3, mice were injected with $250 \mathrm{mg} / \mathrm{kg}$ body weight AICAR in DMSO 5 days/ week for 4 weeks as previously described [25]. Group 4, mice were injected with same doses of rapamycin $(2 \mathrm{mg} /$ $\mathrm{kg})$ and AICAR $(250 \mathrm{mg} / \mathrm{kg})$ in DMSO 5 days/week for 4 weeks. The drugs were injected i.p. under isofluorane inhalation anesthesia (Abbott, Abbott Park, IL). Animals were euthanized and kidneys were removed rapidly to measure tumor size by two independent observers blinded to the experimental conditions. The kidneys were removed rapidly for dissection and bio-chemical analysis. Half of kidney from each mouse was formalin fixed, paraffin embedded and tissue blocks were serially sectioned.

\section{Toxicity assay}

Urinary excretion of glutathione- $S$-transferase (GST) an indicator of the loss of cell membrane integrity was used as a marker of kidney toxicity. GST was measured in urine from all mice groups. In addition, GST was also measured in serum from each mouse. GST was measured using dinitrochlorobenzene and glutathione (GSH) as substrate and co-substrate respectively [26]. Final data represents as one unit of GST activity is the formation of $1 \mu \mathrm{mol}$ of dinitrochlorobenzene GSH conjugate $/ \mathrm{ml} / \mathrm{min}$ at $\mathrm{pH} 6.5$ and $25^{\circ} \mathrm{C}$.

\section{Immunoperoxidase staining of Ki67}

Detection of Ki67 was performed on paraffin kidney tumor sections by immunoperoxidase staining [27]. Kidney sections were incubated with rabbit antiKi67 antibody (Abcam, Cambridge, MA) for $30 \mathrm{~min}$. After washing in PBS, sections were incubated with horseradish peroxidase labeled anti-rabbit antibody for $30 \mathrm{~min}$. The horseradish peroxidase was developed with diaminobenzidine tetrahydrochloride and hydrogen peroxide in PBS. To demonstrate staining specificity, control kidney sections were stained without primary antibody. Kidney sections were viewed and photographed using a Nikon Research microscope equipped for epifluorescence.

\section{TUNEL assay}

Apoptosis in tissue sections was examined using the TUNEL Apoptosis Detection Kit (Upstate) as previously described [20]. Sections incubated in PBS served as the 
negative control. The number of TUNEL-positive cells was counted in five randomly selected fields under $40 \mathrm{X}$ magnification in each kidney section from each animal.

\section{Statistics}

Data are presented as mean \pm standard error. Statistical differences were determined using ANOVA followed by Student Dunnett's (Exp. vs. Control) test using 1 trial analysis. $P$-values less than 0.01 were considered statistically significant.

\section{Author contributions}

Conception and design: S.L. Habib and S. Liang Development of methodology: S. Liang, B Li, M. Nowacki and S.L. Habib

Acquisition of data (provided animals, acquired and managed patients, provided facilities, etc.): S.L. Habib, S. Liang, and T. Cuellar

Analysis and interpretation of data (e.g., statistical analysis, biostatistics, computational analysis): S.L. Habib, S. Liang, M. Nowacki, T. Cuellar and B. Nayak

Writing, review, and/or revision of the manuscript: S.L. Habib, L. Dong, K. Sharma, B Li and B. Nayak.

Administrative, technical, or material support (i.e., reporting or organizing data, constructing databases): S.L. Habib and S. Liang

Study supervision: S.L. Habib and S. Liang

\section{ACKNOWLEDGMENTS}

We thank the Flow Cytometry facilities at UTHSCSA. The study was supported by UTHSCSA grant- 150680 .

\section{CONFLICTS OF INTEREST}

No potential conflicts of interest were disclosed.

\section{REFERENCES}

1. Curatolo P, Bombardieri R, Jozwiak S. Tuberous sclerosis. Lancet. 2008; 372:657-68. https://doi.org/10.1016/S0140-6736(08)61279-9

2. Stillwell TJ, Gomez MR, Kelalis PP. Renal lesions in tuberous sclerosis. J Urol. 1987; 138:477-81. https://doi.org/10.1016/S0022-5347(17)43234-4

3. Al-Saleem T, Wessner LL, Scheithauer BW, Patterson K, Roach ES, Dreyer SJ, Fujikawa K, Bjornsson J, Bernstein J, Henske EP. Malignant tumors of the kidney, brain, and soft tissues in children and young adults with the tuberous sclerosis complex. Cancer. 1998; 83:2208-16.

https://doi.org/10.1002/(SICI)1097-
0142(19981115)83:10<2208::AID-CNCR21>3.0.CO;2-K

4. Harari S, Torre O, Cassandro R, Moss J. The changing face of a rare disease: lymphangioleiomyomatosis. Eur Respir J. 2015; 46:1471-85.

https://doi.org/10.1183/13993003.00412-2015

5. Meraj R, Wikenheiser-Brokamp KA, Young LR, McCormack FX. Lymphangioleiomyomatosis: new concepts in pathogenesis, diagnosis, and treatment. Semin Respir Crit Care Med. 2012; 33:486-97.

https://doi.org/10.1055/s-0032-1325159

6. Washecka R, Hanna M. Malignant renal tumors in tuberous sclerosis. Urology. 1991; 37:340-43.

https://doi.org/10.1016/0090-4295(91)80261-5

7. Travis WD, Colby TV, Corrin B, Shimosato Y, Brambilla E. Histological Typing of Lung and Pleural Tumours. J Clin Pathol. 2001; 54:498-499.

https://doi.org/10.1007/978-3-642-60049-4.

8. Dan HC, Sun M, Yang L, Feldman RI, Sui XM, Ou CC, Nellist M, Yeung RS, Halley DJ, Nicosia SV, Pledger WJ, Cheng JQ. Phosphatidylinositol 3-kinase/Akt pathway regulates tuberous sclerosis tumor suppressor complex by phosphorylation of tuberin. J Biol Chem. 2002; 277:3536470. https://doi.org/10.1074/jbc.M205838200

9. Manning BD, Tee AR, Logsdon MN, Blenis J, Cantley LC. Identification of the tuberous sclerosis complex-2 tumor suppressor gene product tuberin as a target of the phosphoinositide 3-kinase/akt pathway. Mol Cell. 2002; 10:151-62.

https://doi.org/10.1016/S1097-2765(02)00568-3

10. Pugh CW, Ratcliffe PJ. Regulation of angiogenesis by hypoxia: role of the HIF system. Nat Med. 2003; 9:677-84. https://doi.org/10.1038/nm0603-677

11. Gordan JD, Simon MC. Hypoxia-inducible factors: central regulators of the tumor phenotype. Curr Opin Genet Dev. 2007; 17:71-77. https://doi.org/10.1016/j.gde.2006.12.006

12. Shinojima T, Oya M, Takayanagi A, Mizuno R, Shimizu N, Murai M. Renal cancer cells lacking HIF-1 $\alpha$ expression maintains VEGF expression through HIF-2 $\alpha$. Carcinogenesis. 2007; 28:529-36.

https://doi.org/10.1093/carcin/bgl143

13. Dabora SL, Franz DN, Ashwal S, Sagalowsky A, DiMario FJ Jr, Miles D, Cutler D, Krueger D, Uppot RN, Rabenou R, Camposano S, Paolini J, Fennessy F, et al. Multicenter phase 2 trial of sirolimus for tuberous sclerosis: kidney angiomyolipomas and other tumors regress and VEGF- D levels decrease. PLoS One. 2011; 6:e23379.

https://doi.org/10.1371/journal.pone.0023379

14. Kingswood JC, Jozwiak S, Belousova ED, Frost MD, Kuperman RA, Bebin EM, Korf BR, Flamini JR, Kohrman MH, Sparagana SP, Wu JY, Brechenmacher T, Stein K, et al. The effect of Everolimus on renal Angiomyolipoma in patients with TSC being treated for Subependymal Giant cell Astrocytoma: subgroup results from the randomized, 
placebo-controlled, Phase 3 trial EXIST-1. Nephrol Dial Transplant. 2014; 29:1203-10.

https://doi.org/10.1093/ndt/gfu013

15. Cardamone M, Flanagan D, Mowat D, Kennedy SE, Chopra M, Lawson JA. Mammalian target of rapamycin inhibitors for intractable epilepsy and subependymal giant cell astrocytomas in tuberous sclerosis complex. J Pediatr. 2014; 164:1195-200. https://doi.org/10.1016/j.jpeds.2013.12.053

16. Guo D, Hildebrandt IJ, Prins RM, Soto H, Mazzotta MM, Dang J, Czernin J, Shyy JY, Watson AD, Phelps M, Radu CG, Cloughesy TF, Mischel PS. The AMPK agonist AICAR inhibits the growth of EGFRvIII-expressing glioblastomas by inhibiting lipogenesis. Proc Natl Acad Sci USA. 2009; 106:12932-37.

https://doi.org/10.1073/pnas.0906606106

17. Habib SL, Kasinath BS, Arya RR, Vexler S, Velagapudi C. Novel mechanism of reducing tumourigenesis: upregulation of the DNA repair enzyme OGG1 by rapamycin-mediated AMPK activation and mTOR inhibition. Eur J Cancer. 2010; 46:2806-20.

https://doi.org/10.1016/j.ejca.2010.06.117

18. Yu J, Astrinidis A, Howard S, Henske EP. Estradiol and tamoxifen stimulate LAM-associated angiomyolipoma cell growth and activate both genomic and nongenomic signaling pathways. Am J Physiol Lung Cell Mol Physiol. 2004; 286:L694-700.

https://doi.org/10.1152/ajplung.00204.2003

19. Habib SL, Bhandari BK, Sadek N, Abboud-Werner SL, Abboud HE. Novel mechanism of regulation of the DNA repair enzyme OGG1 in tuberin-deficient cells. Carcinogenesis. 2010; 31:2022-30.

https://doi.org/10.1093/carcin/bgq189

20. Velagapudi C, Bhandari BS, Abboud-Werner S, Simone S, Abboud HE, Habib SL. The tuberin/mTOR pathway promotes apoptosis of tubular epithelial cells in diabetes. $\mathrm{J}$ Am Soc Nephrol. 2011; 22:262-73. Corresponding author https://doi.org/10.1681/ASN.2010040352

21. Habib SL. Insight into mechanism of oxidative DNA damage in angiomyolipomas from TSC patients. Mol Cancer. 2009; 8:13. https://doi.org/10.1186/1476-4598-8-13

22. Bradford MM. A rapid and sensitive method for the quantitation of microgram quantities of protein utilizing the principle of protein-dye binding. Anal Biochem. 1976; 72:248-54. https://doi.org/10.1016/0003-2697(76)90527-3

23. Dihlmann S, Kloor M, Fallsehr C, von Knebel Doeberitz M. Regulation of AKT1 expression by beta-catenin/Tcf/Lef signaling in colorectal cancer cells. Carcinogenesis. 2005; 26:1503-12. https://doi.org/10.1093/carcin/bgi120

24. Habib SL, Riley DJ, Mahimainathan L, Bhandari B, Choudhury GG, Abboud HE. Tuberin regulates the DNA repair enzyme OGG1. Am J Physiol Renal Physiol. 2008; 294:F281-90. https://doi.org/10.1152/ajprenal.00370.2007

25. Theodoropoulou S, Brodowska K, Kayama M, Morizane
Y, Miller JW, Gragoudas ES, Vavvas DG. Aminoimidazole carboxamide ribonucleotide (AICAR) inhibits the growth of retinoblastoma in vivo by decreasing angiogenesis and inducing apoptosis. PLoS One. 2013; 8:e52852.

https://doi.org/10.1371/journal.pone.0052852

26. Walshe CM, Odejayi F, Ng S, Marsh B. Urinary glutathione S-transferase as an early marker for renal dysfunction in patients admitted to intensive care with sepsis. Crit Care Resusc. 2009; 11:204-09.

27. Liang S, Cuevas G, Tizani S, Salas T, Liu H, Li B, Habib SL. Novel mechanism of regulation of fibrosis in kidney tumor with tuberous sclerosis. Mol Cancer. 2013; 12:49. https://doi.org/10.1186/1476-4598-12-49.

28. Habib SL. Tuberous Sclerosis complex and DNA Repair. In: Ahmad SI, editor. Diseases of DNA Repair. Landes Bioscience Publications; 2010. pp. 84-94. https://doi.org/10.1007/978-1-4419-6448-9_8.

29. Parry L, Maynard JH, Patel A, Clifford SC, Morrissey C, Maher ER, Cheadle JP, Sampson JR. Analysis of the TSC1 and TSC2 genes in sporadic renal cell carcinomas. Br J Cancer. 2001; 85:1226-30.

https://doi.org/10.1054/bjoc.2001.2072

30. Jozwiak J. Hamartin and tuberin: working together for tumour suppression. Int J Cancer. 2006; 118:1-5.

https://doi.org/10.1002/ijc.21542

31. Sahin M, Henske EP, Manning BD, Ess KC, Bissler JJ, Klann E, Kwiatkowski DJ, Roberds SL, Silva AJ, HillaireClarke CS, Young LR, Zervas M, Mamounas LA, et al, and Tuberous Sclerosis Complex Working Group to Update the Research Plan. Advances and Future Directions for Tuberous Sclerosis Complex Research: Recommendations From the 2015 Strategic Planning Conference. Pediatr Neurol. 2016; 60:1-12. https://doi.org/10.1016/j.pediatrneurol.2016.03.015

32. Habib SL, Al-Obaidi NY, Nowacki M, Pietkun K, Zegarska B, Kloskowski T, Zegarski W, Drewa T, Medina EA, Zhao Z, Liang S. Is mTOR Inhibitor Good Enough for Treatment All Tumors in TSC Patients? J Cancer. 2016; 7:1621-31. https://doi.org/10.7150/jca.14747

33. Pan XD, Gu DH, Mao JH, Zhu H, Chen X, Zheng B, Shan Y. Concurrent inhibition of mTORC1 and mTORC2 by WYE-687 inhibits renal cell carcinoma cell growth in vitro and in vivo. PLoS One. 2017; 12:e0172555.

https://doi.org/10.1371/journal.pone.0172555 